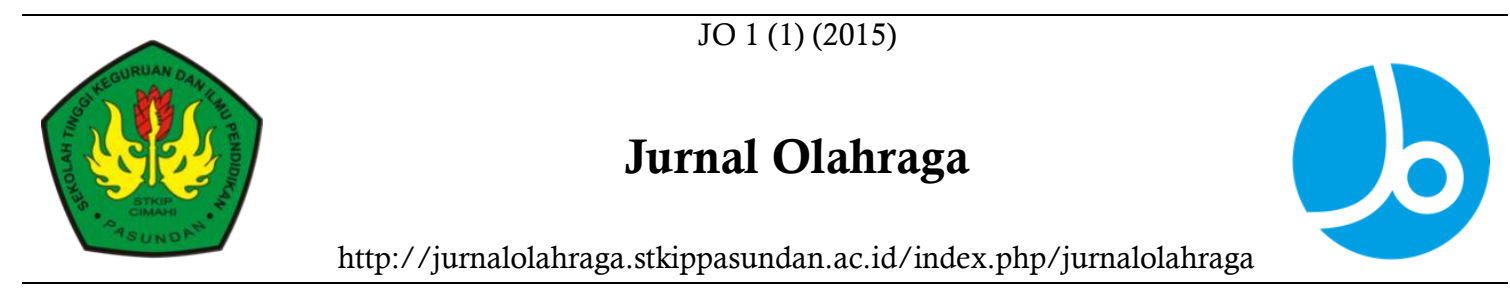

\title{
Pengaruh Model Pembelajaran Kooperatif Tipe TAI (Teams Assisted Individualization) terhadap Sikap Kerjasama dan Sikap Bertanggung Jawab Siswa
}

\begin{tabular}{|c|c|}
\hline & $\begin{array}{c}\text { Muchamad Ishak } \\
\text { STKIP Pasundan, Indonesia }\end{array}$ \\
\hline Info Artikel & Abstrak \\
\hline $\begin{array}{l}\text { Sejarah Artikel: } \\
\text { Diterima Januari } 2015 \\
\text { Disetujui Maret } 2015 \\
\text { Dipublikasikan April } 2015 \\
\text { Keywords: } \\
\text { model kooperatif tipe TAI, } \\
\text { sikap kerjasama, dan sikap } \\
\text { bertanggung jawab }\end{array}$ & $\begin{array}{l}\text { Penelitian ini bertujuan untuk mengungkap efektifitas model } \\
\text { pembelajaran kooperatif tipe TAI dalam meningkatkan sikap } \\
\text { kerjasama dan sikap bertanggung jawab siswa. Model pembelajaran } \\
\text { tersebut lebih menekankan pada penyelesaian permasalahan belajar } \\
\text { setiap individu sebagai tanggung jawab kelompok, sehingga model } \\
\text { tersebut dipercaya akan meningkatkan sikap kerjasama dan sikap } \\
\text { bertanggung jawab. Metode yang digunakan adalah metode } \\
\text { ekperimen dengan desain "randomized control group pretest-posttest } \\
\text { design". Populasi yang menjadi objek dalam penelitian ini adalah } \\
\text { seluruh siswa kelas X SMK PGRI } 3 \text { Cimahi yang berjumlah } 120 \\
\text { orang, sampel diambil sebanyak } 60 \text { orang secara acak. Selanjutnya } \\
\text { dilakukan tes awal sebagai acuan untuk membagi menjadi dua } \\
\text { kelompok yang berbeda yaitu model kooperatif tipe TAI dan model } \\
\text { konvensional. Instrumen yang digunakan berupa angket mengenai } \\
\text { sikap kerjasama dan sikap bertanggung jawab. Data yang diperoleh } \\
\text { dari tes awal dan akhir kemudian diolah dan dianalisis menggunakan } \\
\text { SPSS Serie } 16 \text { dengan tahapan : Uji Normalitas (Kolmogorov- } \\
\text { Smirnov), Uji Homogenitas (Lavene stastistic), Analisis varian } \\
\text { (Independent samples t-test). Hasil penelitian diperoleh Pertama, } \\
\text { Terdapat pengaruh dari model pembelajaran kooperatif tipe TAI } \\
\text { terhadap sikap kerjasama siswa. Kedua, Terdapat pengaruh dari } \\
\text { model pembelajaran kooperatif tipe TAI terhadap sikap bertanggung } \\
\text { jawab siswa. Ketiga, Terdapat pengaruh dari model pembelajaran } \\
\text { konvensional terhadap sikap kerjasama siswa. Keempat, Terdapat } \\
\text { pengaruh dari model pembelajaran konvensional terhadap sikap } \\
\text { bertanggung jawab siswa. dan Kelima, Model pembelajaran } \\
\text { kooperatif tipe TAI lebih baik daripada model konvensional terhadap } \\
\text { sikap kerjasama dan sikap bertanggung jawab siswa. }\end{array}$ \\
\hline
\end{tabular}

\section{Abstract}

This study aims to reveal the effectiveness of the TAI type of cooperative learning model in enhancing students' attitude of cooperation and responsible attitude. The learning model 
emphasizes more on solving individual learning problems as a group's responsibility, so that the model is believed to improve cooperation and responsibility. The method used is an experimental method with a "randomized control group pretest-posttest design" design. The population that became the object of this study were all students of class X SMK PGRI 3 Cimahi totaling 120 people, samples were taken as many as 60 people randomly. Then the initial test is done as a reference to divide into two different groups, namely the TAI type cooperative model and the conventional model. The instrument used in the form of a questionnaire regarding the attitude of cooperation and attitude of responsibility. Data obtained from initial and final tests are then processed and analyzed using SPSS Serie 16 with stages: Normality Test (Kolmogorov-Smirnov), Homogeneity Test (Lavene statistical), Analysis of variance (Independent samples t-test). First, there is an effect of the type of TAI cooperative learning model on student cooperation attitude. Second, there is an influence of the TAI type cooperative learning model on students' responsible attitude. Third, there is an influence of conventional learning models on student cooperation attitude. Fourth, there is an influence of conventional learning models on students' responsible attitudes. and Fifth, the TAI type of cooperative learning model is better than the conventional model of cooperative attitudes and students' responsible attitudes.

(C) 2015 Muchamad Ishak

Under the license CC BY-SA 4.0

$\triangle$ Alamat korespondensi:

ISSN 2442-9661 (cetak)

E-mail: -

\section{PENDAHULUAN}

Masyarakat Indonesia merupakan salah satu bangsa yang terbentuk dari berbagai suku yang memeluk agama dan kepercayaan yang berbeda-beda. Keadaan yang demikian merupakan hal yang membanggakan, sekaligus dibutuhkan kesadaran tinggi dari semua pihak agar tetap terjalin sikap kerjasama yang kokoh hingga sikap bertanggung jawab sebagai dasar dalam menjaga kelestarian keberagaman negara kesatuan republik Indonesia.

Kerjasama merupakan salah satu modal tercapainya suatu tujuan. Dengan adanya usaha bersama antara orang perorangan atau kelompok manusia yang bermaksud mencapai satu atau beberapa tujuan yang dilakukan secara bersama akan lebih mudah dalam pencapaiannya. Sikap kerjasama benar-benar merupakan hal yang sangat penting dimiliki dalam kehidupan manusia termasuk oleh siswa-siswi di sekolah. Sebagai gererasi penerus bangsa sikap tersebut harus tertanam dengan kuat dalam diri mereka, tentunya dalam hal yang positif sebagai landasan dalam menjaga kesatuan bangsa dan negara.

Sikap kerjasama yang dimiliki oleh siswa-siswi kita saat ini cukup tinggi, hanya disayangkan mereka lebih cenderung 
menempatkannya kepada hal-hal yang negatif seperti saling mencontek, bersatu padu dalam menyusun penyerangan saat tawuran hingga kegiatan-kegiatan yang menjurus pada kegiatan kriminal yang dilakukan secara bersama-sama.

Selain sikap kerjasama para siswa juga harus memiliki sikap positif lainnya sehingga saling mendukung dan melengkapi satu dengan lainnya seperti sikap bertanggung jawab. Menurut Magdalena (www.klubsinau) sikap bertanggung jawab adalah perbuatan yang menunjukan terhadap sesuatu kewajiban atau keharusan atau siap menanggung segala sesuatunya. Dengan memiliki sikap bertanggung jawab yang tinggi tentunya segala sesuatu yang dilakukan para siswa akan dipikirkan terlebih dahulu agar akibat yang akan ditimbulkannya tidak merugikan.

Diyakini bahwa orang yang memiliki sikap bertanggung jawab tinggi akan mampu berbuat baik walaupun tidak ada yang melihat, dengan kata lain dia akan berdisiplin terhadap aturan dan norma yang berlaku (Magdalena, 2011 dalam www.klubsinau). Dari penjelasan tersebut penulis meyakini bahwa dalam menanamkan sikap kerjasama kepada siswa harus juga beriringan dengan sikap bertanggung jawab sehingga siswa tersebut mampu bertindak yang terbaik dengan terlebih dahulu memikirkan akibat yang akan ditimbulkannya.

Menanamkan sikap-sikap yang baik merupakan kewajiban semua pihak dimulai dari lingkungan keluarga dilanjutkan ke lingkungan sekolah sehingga akan mampu dan terbiasa bersikap yang terbaik pada lingkungan yang lebih besar yaitu masyarakat. Sebagai praktisi pendidikan hal yang bisa dilakukan adalah melalui peran sekolah karena sekolah merupakan tempat berlangsungnya kegiatan belajar mengajar. Sekolah memiliki peranan strategis dalam mencetak generasi-generasi yang berkualitas baik secara kognitif maupun afektif. Sekolah juga dirancang sebagai lembaga yang bertugas untuk memberikan proses pendidikan formal kepada siswanya, bahkan sekolah bisa dikatakan sebagai penentu akan keberhasilan dari suatu Negara. Anzizham (2008 :1) menjelaskan bahwa :

Pendidikan dijadikan sebagai institusi utama dalam upaya pembentuk sumber daya manusia (SDM) berkualitas yang diharapkan suatu bangsa. Pada gilirannya, pendidikan menjadi taken for granted terkait dengan eksistensi dan kelangsungan hidup (survival) kebudayaan suatu bangsa.

Istilah pendidikan tersebut erat kaitannya dengan institusi atau sekolah, karena itu sekolah sebagai tempat mencetak generasi-generasi muda harus selalu memperhatikan kualitas secara keseluruhan, bukan hanya kemampuan kognitifnya saja tetapi mencakup afektif hingga psikomotornya sebagai bekalnya kelak, seperti yang dikemukakan oleh Harsono (2010: 2) bahwa:

Pendidikan adalah suatu usaha sadar dalam melatih dan memperkembang kecerdasan, keterampilan (skill), akal (mind) dan watak (character) individu, sehingga memungkinkan dia untuk mampu 
menjalani kehidupan secara produktif dan penuh tanggung jawab, mampu menyesuaikan dirinya dengan alam dan masyarakat sekitarnya serta takwa kepada Tuhan Yang Maha Esa.

Pernyataan ini menyiratkan bahwa pendidikan di sekolah memiliki tujuan yang kompleks, bukan hanya sekedar meningkatkan kualitas intelektual semata tetapi mencakup aspek afektif seperti saling menghormati, kerjasama, bertanggung jawab dan aspekaspek positif lainnya yang dapat meningkatkan kualitas kehidupan manusia dimuka bumi ini. Sekolah melalui berbagai mata pelajarannya berusaha untuk dapat mencapai tujuan tersebut termasuk melalui pendidikan jasmani. Seperti yang tertuang dalam Kemendikbud (2010: 1) bahwa :

Pendidikan jasmani merupakan bagian integral dari pendidikan secara keseluruhan, bertujuan untuk mengembangkan aspek kebugaran jasmani, keterampilan gerak, keterampilan berfikir kritis, keterampilan sosial, penalaran, stabilitas emosional, tindakan moral, aspek pola hidup sehat dan pengenalan lingkungan bersih melalui aktivitas jasmani, olahraga dan kesehatan terpilih yang direncanakan secara sistematis dalam rangka mencapai tujuan pendidikan nasional.

Penjelasan Kemendikbud sesuai dengan apa yang dikemukakan Suherman (2009: 7) bahwa terdapat empat kategori tujuan pendidikan jasmani yaitu : “(1) Perkembangan fisik; (2) Perkembangan gerak; (3) Perkembangan mental; dan (4) Perkembangan sosial”. Berdasarkan penjabaran sebelumnya, sudah sangat jelas bahwa tujuan pendidikan jasmani adalah meningkatkan kualitas peserta didik baik aspek psikomotor atau gerak raganya, kognitif atau intelektualnya hingga aspek afektif atau sikapnya yang mencakup sikap kerjasama dan bertanggung jawab.

Namun harapan tersebut sangat bertentangan dengan kondisi yang terjadi saat ini seperti yang telah dijelaskan sebelumnya mengenai kondisi umum siswa-siswi di Indonesia yang menempatkan sikap kerjasama pada sisi yang salah atau dengan kata lain sikap kerjasama yang tidak bertanggung jawab. Padahal siswa-siswi sekolah terutama tingkat SMA merupakan siswa paling tinggi diantara tingkatan lainnya bahkan mereka telah mengenyam pendidikan selama kurang lebih 9 tahun, tetapi seolah proses pendidikan yang telah dilewati tersebut tidak cukup untuk membuat mereka memiliki sikap yang baik termasuk sikap kerjasama dan bertanggung jawab.

Mencermati kondisi yang ada di atas, salah satu hal yang dapat dilakukan terutama oleh guru di sekolah adalah dengan penerapan model pembelajaran yang tepat, karena menurut Good dan Brophy (Rochman, 2013: 4) bahwa "Pemakaian strategi atau pendekatan pembelajaran yang tepat akan memungkinkan beragam tujuan proses pembelajaran lebih mudah untuk dicapai”.

Salah satu model pembelajaran yang dapat digunakan dalam rangka meningkatkan sikap kerjasama dan tanggung jawab adalah cooperative learning karena model ini 
memiliki beragam tipe yang memungkinkan untuk diterapkan dengan menyesuaikan kondisi siswa, sifat dari materi yang akan diajarkan, fasilitas dan media yang tersedia, hingga kondisi dari guru itu sendiri dengan lebih menitikberatkan pada aktivitas yang dilakukan secara bersama.

Model pembelajaran kooperatif merupakan model pembelajaran yang dilakukan dengan cara membagi siswa kedalam kelompok kecil guna menyelesaikan setiap tugas (gerak) yang diberikan oleh guru. Sehingga dari proses yang dilakukan tersebut akan tercipta sikap kerjasama yang baik termasuk muncul sikap bertanggung jawab dari setiap anggota kelompok dalam menyelesaikan setiap tugas yang diberikan oleh guru yang bersangkutan.

Salah satu model pembelajaran yang termasuk ke dalam cooperative learning adalah tipe TAI (Teams Assited Individualization). Model ini dikembangkan oleh Slavin. Tipe ini mengkombinasikan keunggulan pembelajaran kooperatif dan pembelajaran individu. Tipe ini dirancang untuk mengatasi kesulitan belajar secara individu yang dilakukan secara bersama dalam kelompok.

Karena itu penulis sangat tertarik untuk meneliti mengenai pengaruh model pembelajaran kooperatif tipe TAI terhadap sikap kerjasama dan sikap bertanggung jawab siswa yang diintegrasikan melalui pendidikan jasmani.
Model pembelajaran kooperatif tipe TAI merupakan metode mengajar dengan membagi siswa kedalam kelompok-kelompok kecil. Slavin (1995: 2) menjelaskan bahwa:

Cooperative learning refers to instructional methods teachers use to organize students into small groups, in which students work together to help one another learn academic content. Cooperative learning methods are extensively researched, and under certain well-specified conditions they are known to substantially improve student achievement in most subjects and grade levels.

Dalam model pembelajaran kooperatif siswa akan bekerjasama dalam kelompok yang beranggotakan 4-6 orang yang memiliki kemampuan berbeda untuk menguasai materi yang disampaikan oleh guru. Dengan kondisi siswa yang heterogen maka dibutuhkan sikap saling menghargai dan menghormati antar anggota untuk menyelesaikan tugas yang diberikan.

Ciri khas model pembelajaran kooperatif tipe TAI ini adalah setiap siswa secara individual belajar materi pembelajaran yang telah dipersiapkan oleh guru. Hasil belajar individual itu diberikan kepada setiap kelompok dan didiskusikan sebagai bentuk evaluasi serta dibahas oleh anggota kelompok dan semua anggota kelompok bertanggung jawab atas hasil evaluasi tersebut sebagai tanggung jawab bersama. Suyitno (2002: 9) menjelaskan bahwa model pembelajaran TAI memiliki delapan komponen, yaitu :

1. Teams, yaitu pembentukan kelompok heterogen yang terdiri atas empat sampai 
enam siswa berdasarkan tingkat kemampuannya (penguasaan gerak).

2. Placement test, yaitu pemberian pre-test kepada siswa untuk melihat kemampuan awal siswa.

3. Student Creative, melaksanakan tugas dalam suatu kelompok dengan menciptakan situasi dimana keberhasilan individu ditentukan atau dipengaruhi oleh keberhasilan kelompoknya.

4. Team Study, yaitu tahapan tindakan belajar yang dilaksanakan oleh kelompok.

5. Team Scores and Team Recognition, yaitu pemberian skor terhadap hasil kerja kelompok dan memberikan kriteria penghargaan terhadap kelompok yang berhasil secara cemerlang dan kelompok yang dipandang kurang berhasil dalam menyelesaikan tugas.

6. Teaching Group, yaitu pemberian materi secara singkat dari guru menjelang pemberian tugas kelompok.

7. Facts Test, yaitu pelaksanaan tes-tes kecil berdasarkan fakta yang diperoleh siswa.

8. Whole Class Units, yaitu pemberian materi oleh guru kembali diakhir waktu pembelajaran dengan strategi pemecahan masalah.

Berdasarkan penjelasan tersebut, maka model pembelajaran kooperatif tipe TAI dalam prosesnya akan mampu mengembangkan berbagai sikap positif siswa diantaranya sikap kerjasama dan sikap bertanggung jawab. Setiap siswa akan belajar melakukan tugas bersama untuk mencapai tujuan yang sama secara bersama-sama, selain itu setiap siswa memiliki kewenangan dan tanggung jawab yang sama dalam membawa kelompoknya untuk memiliki skor atau nilai tertinggi sehingga dapat dipastikan melalui proses pembelajaran yang dilakukan akan mampu meningkatkan sikap kerjasama dan sikap bertanggung jawab siswa.

\section{METODE}

Dalam penelitian ini penulis mencari pengaruh variabel tertentu terhadap variabel yang lain, maka metode yang paling tepat adalah metode eksperimen. Desain yang digunakan dalam penelitian ini adalah randomized control group pretest-posttest design ( Fraenkel dan Wallen, 2007) akan dijelaskan pada tabel 1 sebagai berikut:

Tabel 1. Randomized Control Group PretestPosttest Design

\begin{tabular}{|l|l|l|l|}
\hline Kelompok & Pretest & Treatment & Posttest \\
\hline Eksperimen & $\mathrm{T}_{1}$ & $\mathrm{X}_{1}$ & $\mathrm{~T}_{2}$ \\
Kontrol & $\mathrm{T}_{1}$ & $\mathrm{X}_{2}$ & $\mathrm{~T}_{2}$ \\
\hline
\end{tabular}

Keterangan :

$\mathbf{T}_{\mathbf{1}}=$ pretest sikap kerjasama dan sikap bertanggung jawab $\mathbf{T}_{\mathbf{2}}=$ posttest sikap kerjasama dan sikap bertanggung jawab $\mathbf{X}_{\mathbf{1}}=$ treatment berupa penerapan model pembelajaran kooperatif tipe TAI bagi kelompok eksperimen $\mathbf{X}_{\mathbf{2}}=$ treatment berupa penerapan model pembelajaran konvensional bagi kelompok kontrol

Langkah penelitian dibuat sebagai rencana atau rancangan kerja dalam penelitian. Oleh karena itu peneliti membuat rencana kerja yang diharapkan dapat membantu dalam melaksanakan penelitian. langkah-langkah yang dilakukan adalah sebagai berikut:

a. Penulis menentukan populasi yang akan dijadikan objek penelitian. 
b. Menentukan jumlah atau ukuran sampel yang akan digunakan, yang dianggap dapat mewakili populasi.

c. Menentukan sampel yang telah diketahui jumlahnya dengan cara melakukan acak (random) terhadap populasi yang ada sehingga semua populasi memiliki kesempatan yang sama untuk menjadi sampel, dilanjutkan dengan tes awal untuk selanjutnya membagi kedalam dua kelompok, yaitu kelompok eksperimen yang diberikan perlakuan model pembelajaran kooperatif tipe TAI dan kelompok kontrol yang diberikan perlakuan model konvensional. Pembagian kelompok tersebut berdasarkan tes awal (pretest) sikap kerjasama dan sikap bertanggung jawab.

d. Memberikan perlakuan (treatment) pada kelompok eksperimen sebanyak 18 pertemuan, yaitu proses pembelajaran pendidikan jasmani dengan menggunakan model kooperatif tipe TAI. Sedangkan pada kelompok kontrol tidak diberikan perlakuan atau proses pembelajaran penjas yang dilakukan seperti biasanya di sekolah tersebut.

e. Melakukan tes akhir (posttest) sikap kerjasama dan sikap bertanggung jawab pada kelompok eksperimen maupun pada kelompok kontrol.

f. Melakukan pengolahan dan analisis data dari hasil pretest dan posttest pada kelompok eksperimen dan kelompok kontrol. g. Menyimpulkan hasil penelitian
Populasi dalam penelitian ini adalah seluruh siswa kelas X di SMK PGRI 3 Cimahi tahun ajaran 2012/2013 yang berjumlah 120 orang, diambil kelas $\mathrm{X}$ karena merupakan kelas awal bagi mereka dalam menempuh pendidikan di tingkat sekolah menengah atas yang tentunya membutuhkan penanaman sikap positif yang lebih baik dan kuat sebelum mereka memasuki jenjang yang lebih tinggi. Sampel diambil sebanyak 60 orang dengan cara acak sederhana menggunakan penomoran sehingga semua populasi memiliki kesempatan yang sama untuk terpilih menjadi sampel. Kemudian dari 60 orang tersebut dilakukan tes awal sikap kerjasama dan sikap bertanggung jawab. Selanjutnya dari hasil tes awal tersebut dijadikan acuan bagi penulis untuk membagi menjadi dua kelompok eksperimen dan kelompok kontrol dengan cara silang sehingga komposisi kemampuan dan jumlah yang sama tiap kelompoknya (30 orang).

Instrumen yang digunakan dalam penelitian ini menggunakan instrumen yang telah digunakan sebelumnya oleh peneliti lain dengan beberapa penambahan dibuat sendiri yang berupa skala sikap yang akan diisi oleh siswa. Sebagai pembanding juga digunakan observasi langsung dari guru yang bersangkutan mengenai sikap kerjasama dan sikap bertanggung jawab selama proses pembelajaran berlangsung.

Penelitian ini dilakukan di SMK PGRI 3 Cimahi yang beralamat di Jl. Terusan Babakan Baru No. 4B Telp. (022) 6631360 
Cimahi. Pada prinsipnya dilihat dari segi materi maupun tujuan yang ingin dicapai baik dari model kooperatif tipe TAI (Teams Assisted Individualization) maupun konvensional itu sama (mengikuti kurikulum yang berlaku), hanya yang membedakan adalah proses pembelajaran yang dilakukan. Dalam setiap pertemuannya, pada model kooperatif tipe TAI selalu dilakukan dengan urutan sebagai berikut:

1. Guru memberikan tugas kepada siswa untuk mempelajari teknik gerak tertentu secara individu sesuai urutan RPP yang telah dibuat.

2. Guru memberikan tes sesuai dengan tugas gerak yang telah diberikan, sekaligus skor atau nilai tersebut digunakan sebagai data awal.

3. Guru membentuk beberapa kelompok dengan komposisi kemampuan yang berbeda berdasarkan data awal yang telah diperoleh.

4. Dari hasil belajar individu yang telah dilakukan, kemudian setiap siswa saling bekerjasama untuk mendapatkan hasil penilaian terbaik (kemampuan gerak yang baik) untuk setiap anggota kelompoknya, yang berarti semua anggota kelompok bertanggung jawab dalam membantu dan meningkatkan kemampuan gerak dari teman yang memiliki kemampuan gerak rendah.

5. Guru membantu apabila ada kelompok yang membutuhkannya. (sesuai kondisi)

6. Guru melakukan tes akhir kepada setiap individu untuk mengetahui peningkatan kemampuan gerak yang dimiliki, sekaligus dapat mengetahui kelompok mana yang peningkatannya tertinggi.

7. Guru memberikan penghargaan kepada kelompok yang memperoleh hasil terbaik.

\section{HASIL DAN PEMBAHASAN}

a. Deskripsi Data Sikap Kerjasama Kelompok Model Kooperatif tipe TAI dan Konvensional

Data pada tabel di bawah ini memberikan gambaran mengenai data yang diperoleh dari kelompok model kooperatif tipe TAI dan konvensional. Data digambarkan dengan format penyajian tabel dan gambar berupa tabel seperti di bawah ini.

Tabel 2. Deskripsi Data Sikap Kerjasama Kelompok Model Kooperatif tipe TAI dan

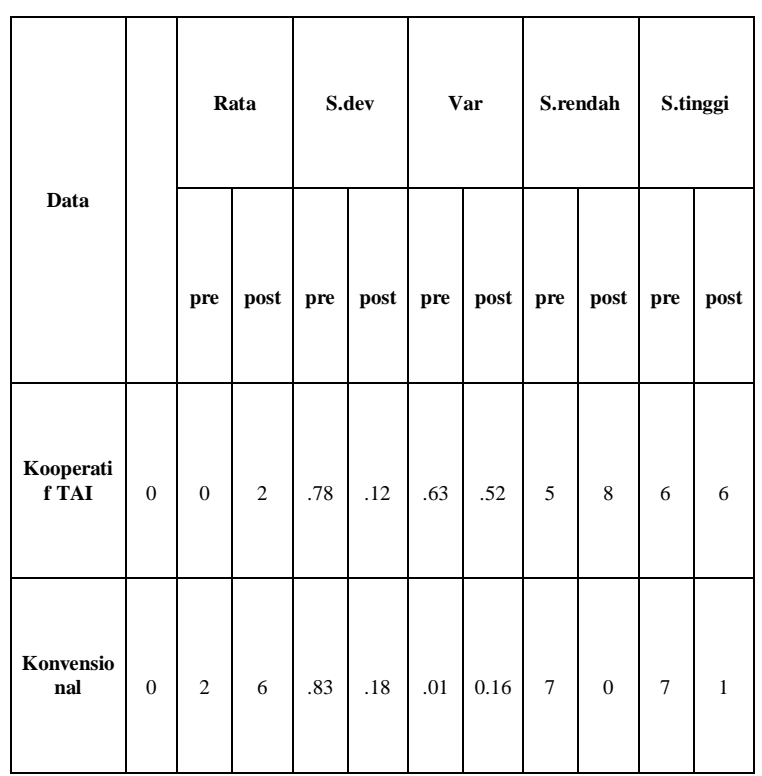

Konvensional 


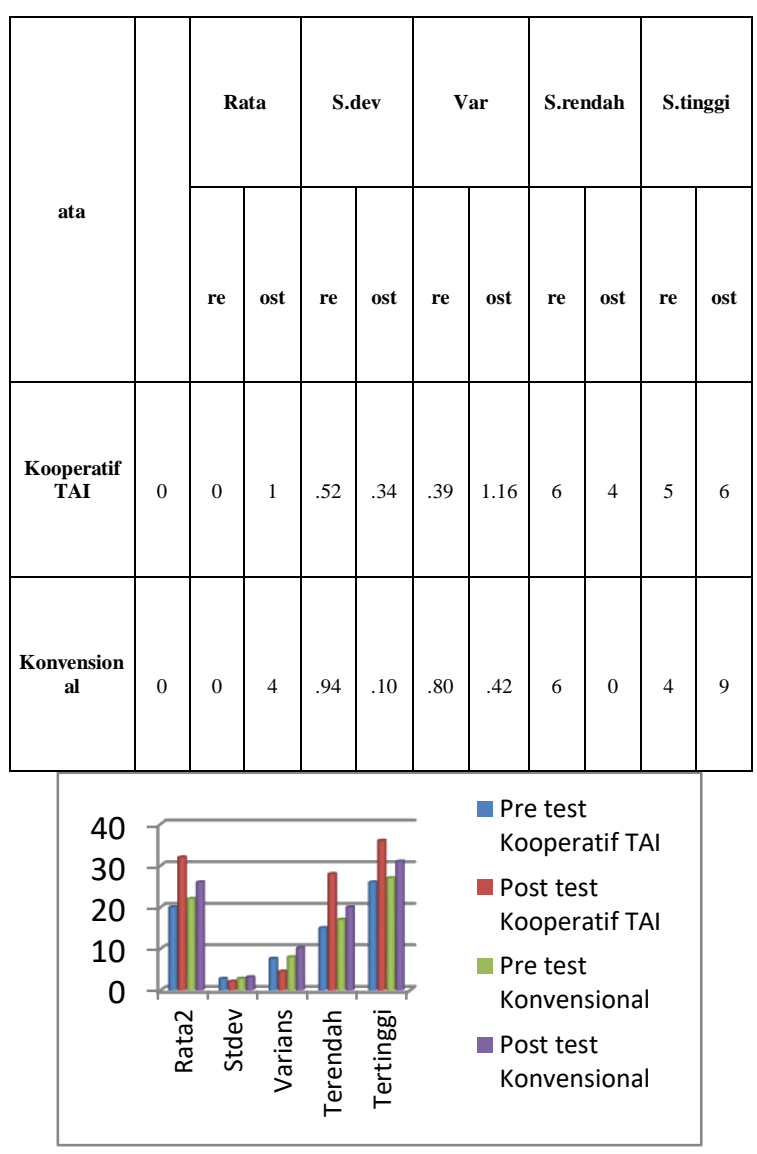

Gambar 1. Deskripsi Data Sikap Kerjasama Kelompok Model Kooperatif tipe TAI dan Konvensional

Dari deskripsi data sikap kerjasama di atas dapat dilihat bahwa terjadi peningkatan rata-rata tes awal jika di bandingkan dengan tes akhir dari masing-masing kelompok. Hal ini dapat diasumsikan bahwa terjadi peningkatan ke arah yang lebih baik mengenai sikap kerjasama yang dimiliki oleh setiap kelompok sampel penelitian tersebut.

b. Deskripsi Data Sikap Bertanggung Jawab Kelompok Model Kooperatif tipe TAI dan Konvensional

Data pada tabel di bawah ini memberikan gambaran mengenai data yang diperoleh dari kelompok model kooperatif tipe
TAI dan konvensional. Data digambarkan dengan format penyajian tabel dan gambar berupa grafik seperti di bawah ini.

Tabel 3. Deskripsi Data Sikap Bertanggung Jawab Kelompok Model Kooperatif tipe TAI dan Konvensional

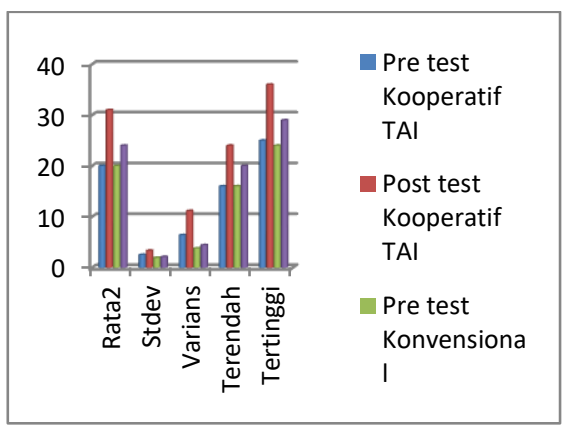

Gambar 2. Grafik peningkatan

Dari deskripsi data sikap bertanggung jawab di atas dapat dilihat bahwa terjadi peningkatan rata-rata tes awal jika di bandingkan dengan tes akhir dari masingmasing kelompok. Hal ini dapat diasumsikan bahwa terjadi peningkatan ke arah yang lebih baik mengenai sikap bertanggung jawab yang dimiliki oleh setiap kelompok tersebut.

c. Deskripsi Data Selisih/Peningkatan Sikap Kerjasama dan Sikap Bertanggung Jawab dari Setiap Kelompok

Tabel 4. Deskripsi Data Selisih/Peningkatan Sikap Kerjasama dan Sikap Bertanggung Jawab dari Setiap Kelompok

\begin{tabular}{|c|c|c|c|c|c|c|c|}
\hline \multicolumn{2}{|c|}{ Selisih } & & $\begin{array}{c}\text { rata- } \\
\text { rata }\end{array}$ & $\begin{array}{c}\text { Standa } \\
\text { Devias } \\
\text { i }\end{array}$ & $\begin{array}{c}\text { Varian } \\
\text { s }\end{array}$ & $\begin{array}{c}\text { Skor } \\
\text { Terenda } \\
\text { h }\end{array}$ & $\begin{array}{c}\text { Skor } \\
\text { Terting } \\
\text { gi }\end{array}$ \\
\hline $\begin{array}{c}\text { Kerjasa } \\
\text { ma }\end{array}$ & $\begin{array}{c}\text { Kooperatif } \\
\text { TAI }\end{array}$ & 0 & 2 & .10 & .44 & 0 & 7 \\
\cline { 2 - 8 }
\end{tabular}




\begin{tabular}{|c|c|c|c|c|c|c|c|} 
& $\begin{array}{c}\text { Konvension } \\
\text { al }\end{array}$ & 0 & & .60 & .53 & & \\
\hline \multirow{2}{*}{$\begin{array}{c}\text { Tanggun } \\
\text { g Jawab }\end{array}$} & $\begin{array}{c}\text { Kooperatif } \\
\text { TAI }\end{array}$ & 0 & 0 & .52 & .32 & & 3 \\
\cline { 2 - 8 } & $\begin{array}{c}\text { Konvension } \\
\text { al }\end{array}$ & 0 & & .27 & .63 & & \\
\hline
\end{tabular}

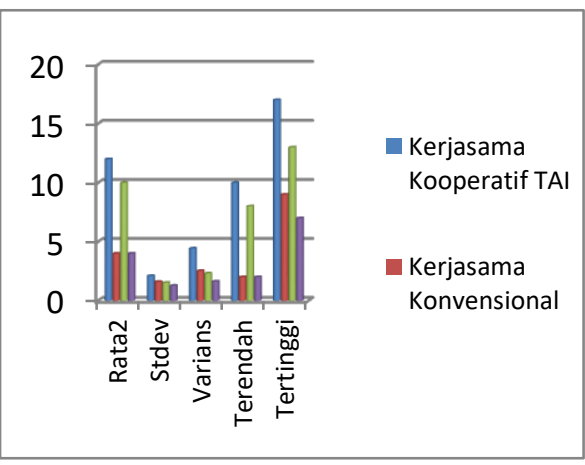

Deskripsi data selisih atau peningkatan antara sikap kerjasama dan sikap bertanggung jawab setiap kelompok dapat dilihat bahwa rata-rata peningkatan pada kelompok model kooperatif tipe TAI lebih tinggi dibandingkan dengan rata-rata kelompok model konvensional. Hal ini dapat diasumsikan adanya perbedaan pengaruh antara kedua model tersebut terhadap sikap kerjasama dan sikap bertanggung jawab.

Uji tersebut dilakukan untuk mengetahui perbedaan pengaruh model kooperatif tipe TAI dengan konvensional terhadap sikap kerjasama juga sikap bertanggung jawab. Pengolahan data dilakukan dengan menggunakan statistik SPSS seri 16.

Hasil pengolahan SPSS diperoleh untuk independent samples t-test ada dua hasil, yaitu uji varians yang berada pada kolom asumsi varians sama dan pada kolom asumsi varians tidak sama. Pengujian terlebih dahulu dilakukan dengan mencari apakah varians kedua kelompok sampel sama atau tidak. Ketentuannya adalah apabila varians kedua kelompok sampel sama maka untuk pengujian rata-rata, nilai-nilai yang digunakan adalah pada kolom baris asumsi varians sama. Sebaliknya apabila hasil pengujian varians kedua kelompok tidak sama, maka untuk pengujian rata-rata nilai angkanya mengacu pada kolom baris asumsi varians tidak sama.

\section{Hasil Uji Independen Sample t-test}

Untuk melihat perbedaan pengaruh antara model kooperatif tipe TAI dengan model konvensional dilakukan dengan menguji perbedaan data selisih pada kedua kelompok, dalam hal ini dilakukan dengan independent sample t-test. 


\section{Uji Kesamaan Varians}

Uji-f ini dimaksudkan untuk menentukan nilai-nilai uji-t pada kolom baris mana yang digunakan untuk menjawab hipotesis penelitian. Apabila berdasarkan uji-f disimpulkan memiliki varians yang sama, maka nilai-nilai uji-t yang digunakan adalah pada kolom baris asumsi varians sama (equal variances assumed). Sebaliknya apabila varians tidak sama, maka nilai-nilai uji-t yang digunakan adalah pada kolom baris asumsi varians tidak sama (equal variances not assumed).

Hipotesis :

$\mathrm{H}_{0}=$ Data memiliki Varians yang sama

$\mathrm{H}_{\mathrm{i}}=$ Data memiliki Varians yang tidak sama

Kriteria Keputusan :

Jika probabilitas (Sig.) > 0,05 maka $\mathrm{H}_{0}$ diterima.

Jika probabilitas (Sig.) $<0,05$ maka $\mathrm{H}_{0}$ ditolak.

Keputusan :

Kerjasama Kooperatif TAI : (Sig,) 0,179 > $0,05\left(\mathrm{H}_{0}\right.$ diterima $)$

Kerjasama Konvensional : (Sig,) 0,457 > 0,05 ( $\mathrm{H}_{0}$ diterima)

Tanggung Jawab Kooperatif TAI : (Sig,) $0,126>0,05\left(\mathrm{H}_{0}\right.$ diterima $)$

Tanggung Jawab Konvensional : (Sig,) 0,707 $>0,05\left(\mathrm{H}_{0}\right.$ diterima $)$

Artinya Data sikap kerjasama dan sikap bertanggung jawab memiliki Varians yang sama. Dengan demikian maka pengujian 
konvensional yaitu 5.781 dengan probabilitas (Sig.) 0,000. Karena probabilitas (Sig.) 0,000 $<0,05$ maka $\mathrm{H}_{0}$ Ditolak. Artinya sikap kerjasama siswa kelompok model kooperatif tipe TAI lebih baik daripada siswa kelompok. Hipotesis Sikap Bertanggung Jawab

$\mathrm{H}_{0}=$ Sikap bertanggung jawab siswa kelompok model kooperatif tipe TAI sama dengan siswa kelompok konvensional.

$\mathrm{H}_{\mathrm{i}}=$ Sikap bertanggung jawab siswa kelompok model kooperatif tipe TAI lebih baik daripada siswa kelompok konvensional.

Kesimpulan Hipotesis Sikap Bertanggung Jawab:

Diketahui nilai $\mathrm{t}_{\text {-hitung }}$ untuk sikap bertanggung jawab kelompok model kooperatif tipe TAI adalah 13.724 lebih besar daripada kelompok konvensional yaitu 8.093 dengan probabilitas (Sig.) 0,000. Karena probabilitas (Sig.) $0,000<0,05$ maka $\mathrm{H}_{0}$ Ditolak. Artinya sikap bertanggung jawab siswa kelompok model kooperatif tipe TAI lebih baik daripada siswa kelompok model konvensional

Pembahasan

Penelitian ini dilakukan untuk mendapatkan jawaban dari pertanyaanpertanyaan penelitian yaitu: Pertama, Apakah model pembelajaran kooperatif tipe TAI berpengaruh terhadap sikap kerjasama siswa. Kedua, Apakah model pembelajaran kooperatif tipe TAI berpengaruh terhadap sikap bertanggung jawab siswa. Ketiga, Apakah model pembelajaran konvensional berpengaruh terhadap sikap kerjasama siswa.
Keempat, apakah model pembelajaran konvensional berpengaruh terhadap sikap kerjasama siswa. dan Kelima, model pembelajaran manakah yang lebih berpengaruh terhadap sikap kerjasama dan sikap bertanggung jawab siswa.

Dari hasil pengolahan dan analisis data yang telah penulis lakukan, diperoleh hasil bahwa; Pertama, terdapat pengaruh dari model pembelajaran kooperatif tipe TAI terhadap sikap kerjasama siswa. Kedua, terdapat pengaruh dari model pembelajaran kooperatif tipe TAI terhadap sikap bertanggung jawab siswa. Ketiga, terdapat pengaruh dari model pembelajaran konvensional terhadap sikap kerjasama siswa. Keempat, terdapat pengaruh dari model pembelajaran konvensional terhadap sikap bertanggung jawab siswa. dan Kelima, model pembelajaran kooperatif tipe TAI lebih baik daripada model konvensional terhadap sikap kerjasama dan sikap bertanggung jawab siswa.

Hasil-hasil jawaban di atas menunjukan bahwa dalam proses pembelajaran setiap guru wajib memiliki kemampuan lebih terutama dalam mengatur proses pembelajaran dengan baik sehingga tujuan utama dapat tercapai. Salah satunya melalui penggunakan model pembelajaran yang tepat guna memastikan setiap proses pembelajaran yang diberikan menjadi lebih bermakna dan memberikan efek yang diharapkan bagi siswanya. Selain itu dengan penggunaan model pembelajaran yang tepat 
diharapkan mampu meminimalisir segala kekurangan yang ada dilapangan seperti permasalahan waktu yang terbatas maupun peralatan yang kurang memadai. Bahkan halhal tersebut bisa dimanfaatkan oleh guru sebagai isu permasalahan yang harus diatasi dan diselesaikan secara bersama oleh siswa sehingga mereka akan terlatih dalam menyelesaikan setiap permasalahan yang terjadi.

Sikap yang baik merupakan salah satu tujuan yang diharapkan setelah melakukan proses pembelajaran, karena siapapun sepakat bahwa tidak cukup hanya pintar atau sehat tetapi siswa-siswi pun harus memiliki sikapsikap yang baik guna menunjang keberhasilnnya dalam mengisi kehidupannya. Karena sikap adalah keadaan diri yang menggerakkan untuk bertindak atau berbuat dalam kegiatan sosial dengan perasaan tertentu didalam menanggapi objek maupun situasi atau kondisi di lingkungan sekitarnya yang bersifat positif maupun negatif .

Ketika guru salah dalam mengarahkan dan memberikan pemahaman serta pengalaman belajar kepada siswa maka hasilnya pun akan salah atau negatif pula. Karena menurut Rahayuningsih (2008) beberapa hal yang sangat mempengaruhi pembentukan sikap diantaranya: Pengalaman pribadi dan sebagai akibat seseorang yang dianggap penting atau berarti dalam hidupnya. Karena itu, guru harus mampu memberikan pengalaman-pengalaman yang positif melalui proses pembelajaran yang diberikan kepada siswanya sehingga sikap yang dihasilkannya pun menjadi positif seperti sikap kerjasama dan bertanggung jawab.

Model pembelajaran kooperatif tipe TAI (Teams Assisted Individualization) merupakan model pembelajaran yang membentuk kelompok kecil yang heterogen dengan latar belakang kemampuan dan cara berfikir yang berbeda-beda untuk saling membantu terhadap siswa lain yang mebutuhkan bantuan. Sementara model pembelajaran konvensional adalah model pembelajaran yang biasa dilakukan oleh guru secara tradisional atau lebih menekankan pada resitasi konten tanpa memberikan waktu yang cukup kepada siswa untuk merefleksi materimateri yang dipresentasikan, tanpa menghubungkannya dengan pengetahuan sebelumnya, atau tanpa mengaplikasikannya kepada situasi kehidupan nyata.

Sikap Kerjasama adalah suatu kegiatan atau usaha yang dilakukan oleh beberapa orang untuk mencapai tujuan bersama. Sikap Bertanggung jawab adalah suatu perbuatan yang menunjukan terhadap sesuatu kewajiban atau keharusan atau siap menanggung segala sesuatunya.

Menurut Johnson et al. (Lie, 2008) sikap kerjasama pada dasarnya dimiliki oleh siswa manapun hanya pertanyaannya apakah siswa tersebut mampu atau tidak untuk mengeksploitasi dan menerapkan sikap kerjasama tersebut dalam proses belajar atau hal positif lainnya. 
Sikap bertanggung jawab yang dimiliki seseorang tidak muncul begitu saja. Tanggung jawab akan muncul bila didasari oleh karakter yang baik. Karakter yang baik akan tumbuh pada diri anak bila dia terbiasa melakukan hal-hal yang baik. Lickoma (1992: 39) menyatakan "good character consist of knowing the good, desiring the good and doing the good-habits of the mind, habits of the heart and habits of action".

Manusia tidak tumbuh menjadi manusia yang bermoral dengan sendirinya, akan tetapi terjadi melalui proses pendidikan. Begitu pula sikap bertanggung jawab harus dibina sejak dini dari semua lingkungan terutama keluarga dan diteruskan di sekolah serta masyarakat secara luas.

Muhibbinsyah dalam Berliana (1998: 35) menyatakan bahwa 'moral, kesusilaan tidak mungkin diajarkan secara teoritis, melainkan harus diajarkan dengan menjalankannya'. Karena itu dalam mengajarkan sikap bertanggung jawab harus dimulai sejak dini kepada anak dari hal-hal yang kecil seperti mengajarkan untuk membereskan mainan yang selesai digunakan, mencontohkan perilaku-perilaku yang baik dan penuh tanggung jawab dilingkungan keluarga, sehingga pada usia sekolah anak sudah terbiasa untuk membawa hal-hal positif tersebut ke sekolah.

Karena itu dalam meningkatkan sikap-sikap positif bagi siswa setiap guru harus memiliki formula-formula terbaru yang berbeda dari proses pembelajaran yang biasa diterapkan. Model pembelajaran tersebut harus bisa menggiring dan mengkondisikan siswa kepada hal-hal yang secara nyata mereka rasakan sehingga pengalaman pembelajaran tersebut akan menetap dengan kuat kepada diri setiap siswanya seperti model pembelajaran kooperatif tipe TAI dalam upaya meningkatkan sikap kerjasama dan sikap bertanggung jawab siswa.

Model pembelajaran kooperatif tipe TAI merupakan strategi pembelajaran yang berpusat pada siswa (student centered). Pada model pembelajaran ini, siswa dibagi kedalam tim belajar yang terdiri atas empat atau lima orang siswa yang rata-rata memiliki tingkat kemampuan yang berbeda, terlepas dia jenis kelamin dan latar belakang etniknya. Guru menyampaikan pelajaran lalu siswa bekerja dalam tim mereka untuk memastikan bahwa semua tim sudah menguasai pelajaran, tipe TAI menggunakan campuran kemampuan semua anggota dalam kelompok dan memberikan penghargaan untuk tim yang terbaik.

TAI dirancang untuk menyelesaikan masalah-masalah teoritis dan praktis dari sistem pengajaran individual serta dapat meminimalisir keterlibatan guru. Hasil belajar siswa secara individual didiskusikan dalam kelompok. Dalam diskusi kelompok setiap anggota kelompok saling mengevaluasi setiap kekurangan dalam kelompoknya, mengevaluasi hasil gerak teman satu kelompok. Guru kembali memberikan tes kemampuan secara individual. Serta diakhiri 
dengan guru memberikan penghargaan kepada kelompok berdasarkan perolehan peningkatan hasil belajar individual dari tes awal ke tes berikutnya.

\section{KESIMPULAN}

Kesimpulan yang dapat diambil dari hasil analisis dan pembahasan mengenai Pengaruh Model Pembelajaran Kooperatif tipe TAI (Teams Assisted Individualization) Terhadap Sikap Kerjasama dan Sikap Bertanggung Jawab Siswa yang mengacu kepada rumusan masalah penelitian adalah sebagai berikut :

1. Terdapat pengaruh dari model pembelajaran kooperatif tipe TAI (Teams Assisted Individualization) terhadap sikap kerjasama siswa.

2. Terdapat pengaruh dari model pembelajaran kooperatif tipe TAI (Teams Assisted Individualization) terhadap sikap bertanggung jawab siswa.

3. Terdapat pengaruh dari model pembelajaran konvensional terhadap sikap kerjasama siswa.

4. Terdapat pengaruh dari model pembelajaran konvensional terhadap sikap bertanggung jawab siswa.

5. Model pembelajaran kooperatif tipe TAI (Teams Assisted Individualization) lebih baik daripada model konvensional terhadap sikap kerjasama dan sikap bertanggung jawab siswa.
Anzizham, S. (2008). Manajemen Lembaga Pendidikan Islam. Jakarta. PT. Ciputat Press Jakarta

Arikunto, S. (1989). Manajemen Penelitian. Jakarta : Depdikbud Dikti P2LPTK.

Asma, N. (2006). Model Pembelajaran Kooperatif. Jakarta : Depdiknas.

Fraenkel, J.R. dan Wallen, N.E. (2007). How To Design and Evaluate Research In Education. San Francisco University.

Good, T L \& Brophy, J E. (1999). Educational Phsycology : a Realitic Approach. New York \& London : Longmann

Harsono. (2010). Sasaran Pendidikan Jasmani. Seminar dan Lokakarya Pengembangan. Program Studi Pendidikan Jasmani FPOK-UPI.

Isjoni. (2009). Cooperative Learning. Bandung : Alfabeta.

Kemendikbud. (1997). Standar Kompetensi dan Kompetensi Dasar. Pendidikan Jasmani, Olahraga dan Kesehatan

Lie, A. (2008). Kooperatif Learning. Jakarta : PT Grasindo.

Lutan, R. (1997). Modifikasi Cabang Olahraga dan Model Pembelajarannya dalam Penyelenggaraan Pendidikan Jasmani di Sekolah Dasar. Laporan Penelitian II. Hibang Bersaing. Bandung : Depdikbud IKIP Bandung.

(2003). Strategi Pembelajaran Pendidikan Jasmani dan Kesehatan. Jakarta. Universitas Terbuka.

Magdalena, M. (2011). Membantu Anak Mengembangkan Sikap Bertanggung Jawab. [Online]. Tersedia: www.klub sinau.home education Indonesia. [18 Januari 2012].

\section{DAFTAR PUSTAKA}


Slavin, R. (2005). Cooperative Learning Teori, Riset dan Praktik. Bandung : Nusa Media.

Suherman, A. (2009). Model Pembelajaran Pendidikan Jasmani : Alternatif Pengembangan dan Implementasi Model Pembelajaran dalam Pengajaran Pendidikan Jasmani. UPI-FPOK.

Sugiyono. (2010). Metode Penelitian Kuantitatif, Kualitatif dan R\&D. Bandung : CV Alfabeta. 